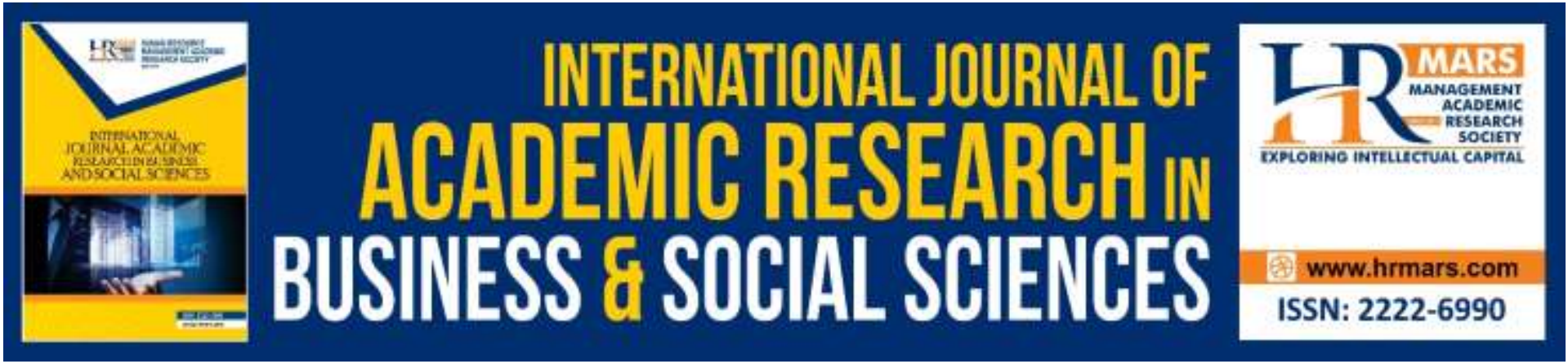

\title{
A Three-Factor Model of Organizational Socialization Tactics: Impact on Job Satisfaction among Engineers in Malaysia
}

\author{
Arnida Jahya, Nurul Ezaili Alias, Rozana Othman, Noor Rafhati Romaiha
}

To Link this Article: http://dx.doi.org/10.6007/IJARBSS/v9-i9/6342

DOI: $10.6007 /$ IJARBSS/v9-i9/6342

Received: 02 August 2019, Revised: 29 August 2019, Accepted: 01 September 2019

Published Online: 24 September 2019

In-Text Citation: (Jahya, Alias, Othman, \& Romaiha, 2019)

To Cite this Article: Jahya, A., Alias, N. E., Othman, R., \& Romaiha, N. R. (2019). A Three-Factor Model of Organizational Socialization Tactics: Impact on Job Satisfaction among Engineers in Malaysia. International Journal of Academic Research in Business and Social Sciences, 9(9), 663-675.

Copyright: (C) 2019 The Author(s)

Published by Human Resource Management Academic Research Society (www.hrmars.com)

This article is published under the Creative Commons Attribution (CC BY 4.0) license. Anyone may reproduce, distribute, translate and create derivative works of this article (for both commercial and non-commercial purposes), subject to full attribution to the original publication and authors. The full terms of this license may be seen

at: http://creativecommons.org/licences/by/4.0/legalcode

Vol. 9, No. 9, 2019, Pg. $663-675$

http://hrmars.com/index.php/pages/detail/IJARBSS

JOURNAL HOMEPAGE

Full Terms \& Conditions of access and use can be found at

http://hrmars.com/index.php/pages/detail/publication-ethics 


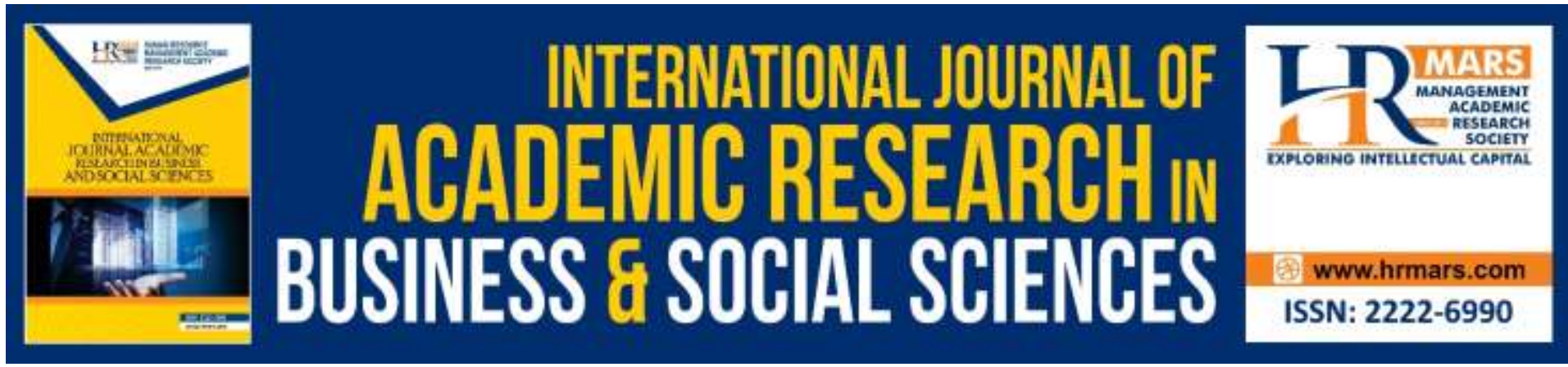

\title{
A Three-Factor Model of Organizational Socialization Tactics: Impact on Job Satisfaction among Engineers in Malaysia
}

\author{
Arnida Jahya ${ }^{1}$, Nurul Ezaili Alias ${ }^{1}$, Rozana Othman ${ }^{1}$, Noor \\ Rafhati Romaiha \\ 'Department of Human Resource Management, ${ }^{2}$ Department of Marketing and \\ Management, Faculty of Business and Management, Universiti Teknologi Mara Melaka, \\ UiTM Melaka Kampus Bandaraya, 110, Off Jalan Hang Tuah, 75300 Melaka. \\ Email: arnida@uitm.edu.my
}

\begin{abstract}
Newcomers' job satisfaction in the socialization literature is still scarce. Thus, the current study investigates the impact of three-factor model of organizational socialization tactics in predicting job satisfaction among engineers in Malaysia. Self-administered research questionnaires were distributed online, and the data were collected from 254 engineers in Malaysia. IBM SPSS version 24 was used to analyze Pearson's Correlation and Multiple Regression. The results from Pearson's Correlation reveals that the three factors of organizational socialization have significant relationship with job satisfaction. The standardized coefficient shows that content tactics have the greatest impact on the outcome variable. This is a cross-sectional study. Thus, it is recommended that future study can do a longitudinal study to examine the change of organizational socialization in different phases. Plus, gender plays a very important role as male and female react to socialization tactics differently. Thus, adding new evidence how female engineers adjust themselves in a maledominated workplace.
\end{abstract}

Keywords: Context Tactics, Content Tactics, Social Tactics, Job Satisfaction, Engineers

\section{Introduction}

A satisfied employee is one of the key elements of the overall health of an organization. A happy employee would love to engage more to their work (Abraham, 2012), put more commitment towards achieving the organizational goal (Ismail and Razak, 2016), avoid the unethical behavior at work (Judge, Timothy, Weiss, Kammeyer-Mueller and Hulin, 2017) and ultimately can reduce the propensity to leave the organization (Mathieu, Fabi, Lacoursière and Raymond, 2015). Thus, it is highly important to identify factors that may lead to greater satisfaction among employee. 
Job satisfaction has been studied for about 100 years (Mitchell and Larson, 1987; Quarstein, McAfee and Glassman, 1992; Judge et al., 2017). Due to the significant interest among scholars and industrial practitioner and its major impact towards organizational performance, research on job satisfaction is remain relevant to be conducted in various perspectives. One of the important jobs that provide great contributions to Malaysia development is engineer.

Since Malaysia gained independence from British in 1957, economic development was largely depending on the agricultural industry. Over the years, Malaysia moves from farmbased economy towards manufacturing industries where the engineering jobs are highly demanded. A lot of tertiary education programs and scholarship were offered to local students to pursue their studies in engineering in Malaysia or abroad to fulfill the engineering jobs. To date, the total number of registered engineers with Board of Engineers Malaysia is more than 90,000 . However, these numbers are too far away from the targeted 200,000 of engineers in Malaysia by 2020. A lot of effort needs to be done by the government together with the companies and universities to attract more students to pursue engineering program. In 2012, Talent Corporation Malaysia Berhad (TalentCorp) has developed a 'Talent Roadmap 2020' for establishing Malaysia as a 'talent hub' with a significant concentration on the engineering profession. This is particularly important as engineering sector is the future driver for Malaysia to be a high-technology and science-based country. Thus, to increase student enrollment in engineering is urgently needed.

It is clear by now that engineering job is paramount to the development of Malaysia. According to JobStreet.com's Employee Job Happiness Index 2017 survey, engineering is one of the happiest jobs in Malaysia (Ho, 2018). However, the number of engineers dropped out of the profession in Malaysia is at an alarming stage, especially among young engineers (Chin, 2019) who are just started their career in a particular organization. As job satisfaction is one of the main predictors of turnover behavior, satisfaction among young engineers is questionable and demand further investigation. Furthermore, engineering job is among the most stressful jobs (Terry and Thomas, 1987) and technical skills are highly sought. Thus, seeking for an explanation of whether a newly recruited engineer is well adjusted in their organization and influence satisfaction.

\section{Significance of the Study}

Considerable amount of literature has been published on job satisfaction. Previous research has established that job satisfaction is often associated with benefit, co-workers' support, managerial support and work condition. Yet, from the perspective of socialization, it was not clear how early work adjustment can be related to job satisfaction in engineering context. Although a few (e.g. Wang et al., 2017; Song et al., 2015, Vitell \& Singhapakdi, 2008) have studied the job satisfaction and work adjustment among novice employees, there has thus far been no study concerning how these constructs relate to each other among newly hired engineers in Malaysia. Thus, for current research, job satisfaction becomes the focus of the study, and the impact of organizational socialization tactics is examined. This study has contributed to the job satisfaction and socialization literature particularly in the context of engineering. Furthermore, the finding of this research is expected to suggest the employer and HR practitioners in determining the best socialization strategy for engineers to establish fit with the organization. 


\section{Purpose of the Study}

The purpose of this research is to investigate the relationship between organizational socialization tactics and job satisfaction among engineers. Thus, the following research objectives guided this study:

- To investigate the relationship between context tactics, content tactics and social tactics with job satisfaction among engineers in Malaysia;

- To determine which tactic has the greatest impact on job satisfaction among engineers in Malaysia.

This study is one of a few that provide evidence the association of mentioned variables among engineers in the local context. The findings of this research are expected to enhance the body of knowledge, especially from the Asian point of view. Also, it helps future researchers and the industry to find a solution to employee dissatisfaction and how organizational socialization tactics can be utilized to improve satisfaction among engineers specifically.

\section{Literature Review Job Satisfaction}

To date, there is no a general agreement on the definition of job satisfaction (Aziri, 2011) because of the concept has been referred interchangeably with other job attitudes constructs such as commitment, morale and involvement (Judge et al., 2017). In general, job satisfaction explains the individual's feelings about their job including related to the work tasks, pay, job promotion and the relationship with the organizational member such as supervisor and colleagues (Weiss, 2002; Brayfield \& Rothe, 1951). The other most cited definition of job satisfaction has been explained meticulously by Spector (1997) in his book Job satisfaction: Application, assessment, causes and consequences. Spector defined job satisfaction as the feelings of the employee, whether they like or dislike their job. It can be concluded that the definition of job satisfaction is quite straight forward, either employee like or dislike their job. And this feeling may come from various factors either from inside the organization or outside.

It is interesting to explore what makes people feel satisfied with their works as we ourselves are being employed and what makes us feel happy to work is particularly important to the organization. Hence, research on job satisfaction has attracted many researchers to explore from different point of view. According to Judge et al. (2017), the first empirical research on job satisfaction was conducted by Thorndike in 1917 among 29 workers. The research aims to investigate the level of satisfaction in comparison to the number of outputs produced and production period. It is believed that the research on job satisfaction became popular since 1930s when Fisher and Hanna (1931) did a case study on dissatisfied employee. In 1934, Uhrbrock conducted empirical research on employee attitude among 4430 factory employees in a large manufacturing company in the United States. A year later, Hoppock (1935) wrote a book titled "Job Satisfaction" and since then, the term becomes more popular among organizational behavior researchers.

One of the most popular theories on job satisfaction is Herzberg's Two Factor Theory in his popular book "One More Time: How do You Motivate Employees." He argued that employees would be satisfied or dissatisfied due to several job-related factors. Among the factors for job satisfaction are achievement and advancement in career, recognition, the nature of work itself, and responsibility. Meanwhile, the factors for job dissatisfaction are 
poor supervision, weak relationship with supervisor and peers, unfavorable work conditions, and low salary. Even though job satisfaction can be considered as a single concept, Özpehlivan and Acar (2015) have modified job satisfaction dimension into relationship with management, relationship with co-workers, job and working conditions, promotion, pay, and external environment. This is consistent with findings by Alegre, Mas-Machuca and Berbegal-Mirabent (2016) whereby job satisfaction is a combination of factors that come from the relationship of employee and the organization, supervisor and coworker. A sound relationship is expected to contribute to a greater performance of the individual as well as the department and ultimately the organization (Bakotić, 2016). Furthermore, job satisfaction has been found to predict various employee outcomes such as work engagement (Yalabik and Rayton, 2017), organizational commitment (Hashim, 2015), lower job stress (Hayes et al., 2015) and retention (Adegoke et al., 2015).

To the best of the researchers' knowledge, there is a dearth of empirical studies that investigate the extent to which organizational socialization tactics influence job satisfaction in engineering context. Thus, this research aims to address this lacuna and generate evidence from the non-western perspective. Besides, the findings of this study are expected to help the organization to have a better plan for on-boarding programs that suit the newly recruited engineers.

\section{Organizational Socialization Tactics}

Maanen and Schein (1979, p.211) defined organizational socialization as "the process by which an individual acquires the social knowledge and skills necessary to assume an organizational role." At this early stage of employment, newcomers experience high tension to adapt to the new work environment due to unfamiliar with organizational culture, procedure, and system. Consequently, employees will develop attitudes and behavior that are necessary to the organization and acceptable to the social group by observing and seeking information that relevant to them. Therefore, socialization will be the medium to provide newcomers with accurate and preliminary information in terms of a realistic job preview when entering the organization.

Maanen and Schein (1979) have identified six dimensions or strategies of socialization, namely, formal-informal, collective-individual, sequential-nonsequential, fixed-variable, serial-disjunctive, and investiture-divestiture. In 1986, Jones in his empirical works on socialization enhanced the theory by grouping the formal, collective, sequential, fixed, serial and investiture in institutionalized continuum and informal, individual, nonsequential, variable, disjunctive and divestiture as individualized tactics. These two classifications of tactics can be differentiated by looking at the roles and initiatives of organization and individual employee in adjustment phases.

In institutionalized tactics, the employer plays a major role to facilitate the learning and adjustment process of new employee. This can be seen through a formal socialization program, consist of structured induction program for all newcomers, structured learning stages, standardize learning schedule, assigning role model and organization will accept the incoming identity of the newcomers. In contrast, individualized tactics refer to when the new employee initiate the strategy to adjust themselves in the organization. They will be isolated from the other newcomers who will require on the job learning. Individualized tactics also did not separate the newcomer and existing member which will allow greater organizational 
assimilation, offers a flexible learning process and stages, did not provide a role model and employee are needed to develop new self-image based upon the requirement of new role.

In the same research, Jone (1986) classified the six variables of socialization tactics into three major factors which are context tactic (collective and formal), content tactic (sequential and fixed) and social tactic (serial and investiture). Context tactics refer to the condition in which newcomers are socialized. The content tactics explain the information provided to facilitate the socialization proses. And social tactics tell about the social aspects of socialization. For new employee to effectively integrated with the whole organizational system, they require proper learning support from the organization, sufficient information, and good fit with the organizational members. New employees who can understand the task and accepted as members by existing colleagues will be adjusted well in the organization (Bauer et al., 2007).

Past research revealed that these three major tactics have a different impact on newcomers' adjustment and other employee outcomes. For instance, Allen \& Shanock (2013) reported that only content and social tactics were related to the level of embeddedness of employees. Sufficient information about the task will enhance the employee's self-efficacy in performing his job. Plus, the fit with organizational members makes the adjustment process easier as newcomers feel a part of the workgroup.

Effective socialization can have long-lasting, productive impacts on employees by increasing the value congruence between employee and organization as well as the emotional attachment to the organization. Research has shown that effective socialization process has an impact on attitude and behavior of employee. Wanous (1992) reported that effective socialization among new hire would help the employee to create new identity that will fit with the work values and norms, adapt with the new work roles, develop work competencies and accept the organizational culture and practices. This is also supported by Bauer et al. (2007) whereby employee who understands the tasks, confidence in performing the task and able to adjust with the workgroup will give a significant impact towards job satisfaction, job performance, organizational commitment, retention, and job turnover. Therefore, for current study, the effect of three-model factors of socialization tactics towards job satisfaction among the engineers has been revealed.

\section{Methodology}

A self-administered questionnaire has been developed in Qualtrics software. Job satisfaction was assessed by using three items of Michigan Organizational Assessment Questionnaire Job Satisfaction Subscale developed by Cammann, Fichman, Jenkins, and Klesh (1979) with an average composite $\alpha=0.872$. The items are "All in all, I am satisfied with my job," "In general, I don't like my job" and "In general, I like working here." This instrument has been employed to measure job satisfaction worldwide and in different context (Bowling and Hammond, 2008). To measure organizational socialization tactics, scales developed by Cable and Parson (2001) was used. It has 12 high-loading items socialization scale with $\alpha=0.811$ that consist of four items for every three major tactics, namely context tactics, content tactics, and social tactics. Example of the item to measure the context tactics is "This organization puts all newcomers through the same set of learning experiences." The respondents have to indicate their level of agreement to all statements based on 7-point scale ranging from $1=$ strongly agree to 7 = strongly disagree. Both Cronbach's alpha coefficient is above 0.7, which show the measurement is reliable and can be accepted for the study. 
As discussed in the previous section, organizational socialization is an adjustment process among employees that are newly recruited and have gone through the on-boarding process. Although past researchers did not have a general agreement when the commencement and ending point of socialization (Ashforth, Sluss and Herrison, 2007), some suggestions have been made when organizational socialization is taking place such as up to 1 year (Bauer \& Green, 1994), less than 2 years (Lee and Allen, 1982), and up to 3 years (Morrison and Vancouver, 2000). While Yang (2010) argued that organizational socialization is an ongoing process that is taking place in the entire organizational tenure of the employees. Despite that, organizational tenure that commonly used in socialization research is between two to three years (Rollag, 2004). For the purpose of current study, 254 engineers that being employed up to two years in the current organization were selected as the respondents.

Even though the respondents come from diverse job position such as junior/graduate/trainee engineer, engineer, senior engineer, managerial/lead/principal engineers and other position, for the purpose of current research, the respondents are referred to engineers. That is not the intention of the study to give greater attention to the job position of the respondents and its effect.

\section{Findings}

\section{Demographic Analysis}

The data have been collected from 254 engineers in Malaysia who are working in their organization for up to two years. Out of 254, 121 (47.64\%) engineers are working less than one year, and 133 (52.36\%) are being employed for up to two years. As engineering is a maledominated profession, majority of the respondents or $185(72.83 \%)$ are males, and 69 $(27.17 \%)$ are females. The respondents were predominately between the age of $25-34$ (67.71\%), followed by age 24 and below at $29.13 \%$ or 74 engineers. A majority $(71.65 \%)$ of the respondents are among engineers, followed by $17.72 \%$ were junior/graduate/trainee engineers. The rest of the respondents are senior engineers (6.69\%), manager/lead/principal engineer $(0.79 \%)$, and other position (3.15\%). There are various engineering backgrounds but commonly characterized by five main branches. $34.65 \%$ or 88 respondents have mechanical background, followed by other background (20.87\%), electronics (17.32\%), chemical (11.81\%), civil/structural (8.27\%) and electrical (7.09\%). The respondents also need to provide information regarding their employment sectors whereby 11 options have been given which are construction, infrastructure, oil and gas, manufacturing, government or local authority, power, education, trading or service transportation, agriculture, ICT and others. Most of the respondents come from manufacturing and oil and gas sector, which are $37.01 \%$ and $20.47 \%$ respectively. Table 1 depicts the summary of demographic data of the study. 
Table 1: Demographic Analysis

\begin{tabular}{|c|c|c|c|}
\hline Variables & & Frequency & $\%$ \\
\hline \multirow[t]{5}{*}{ Age } & 24 and below & 74 & 29.13 \\
\hline & $25-34$ & 172 & 67.72 \\
\hline & $35-44$ & 7 & 2.76 \\
\hline & 45 and above & 1 & 0.39 \\
\hline & TOTAL & 254 & 100 \\
\hline \multirow[t]{3}{*}{ Gender } & Male & 185 & 72.83 \\
\hline & Female & 69 & 27.17 \\
\hline & TOTAL & 254 & 100 \\
\hline \multirow{7}{*}{$\begin{array}{l}\text { Engineering } \\
\text { disciplines }\end{array}$} & Civil/Structural & 21 & 8.27 \\
\hline & Mechanical & 88 & 34.65 \\
\hline & Electrical & 18 & 7.09 \\
\hline & Chemical & 30 & 11.81 \\
\hline & Electronics & 44 & 17.32 \\
\hline & Others (Please specify) & 53 & 20.87 \\
\hline & TOTAL & 254 & 100 \\
\hline \multirow{13}{*}{$\begin{array}{l}\text { Employment } \\
\text { sectors }\end{array}$} & Construction/Properties & 21 & 8.27 \\
\hline & Infrastructure Project & 9 & 3.54 \\
\hline & Oil \& Gas & 52 & 20.47 \\
\hline & Manufacturing & 94 & 37.01 \\
\hline & Govt./Local Authority & 4 & 1.57 \\
\hline & Power & 11 & 4.33 \\
\hline & University/College & 1 & 0.39 \\
\hline & Trading/Service & 2 & 0.79 \\
\hline & Transportation & & \\
\hline & Agriculture & 1 & 0.39 \\
\hline & $\mathrm{ICT}$ & 13 & 5.12 \\
\hline & Others (Please specify) & 46 & 18.11 \\
\hline & TOTAL & 254 & 100 \\
\hline \multirow[t]{6}{*}{ Job position } & $\begin{array}{l}\text { Junior/Graduate/Trainee } \\
\text { Engineer }\end{array}$ & 45 & 17.72 \\
\hline & Engineer & 182 & 71.65 \\
\hline & Senior Engineer & 17 & 6.69 \\
\hline & $\begin{array}{l}\text { Manager/Lead/Principal } \\
\text { Engineer }\end{array}$ & 2 & 0.79 \\
\hline & Others (Please specify) & 8 & 3.15 \\
\hline & TOTAL & 254 & 100 \\
\hline
\end{tabular}




\section{Pearson's Correlation Coefficient}

Correlation between context tactics, content tactics, and social tactics with job satisfaction is presented in Table 2 . The results show that there is a significant relationship between organizational socialization tactics and job satisfaction among the engineers at significant level $.000(p<.001)$. According to Dancey \& Reidy's (2011) rules of thumb for correlation coefficient, correlation between 0.4 to 0.6 is considered moderate, and 0.1 to 0.3 is deemed to be weak relationship. Therefore, content tactics and social tactics have a moderate relationship with job satisfaction with $r=0.489$ and $r=0.443$, respectively. While there is a weak correlation between context tactics and job satisfaction with correlation coefficient at 0.238 .

Table 2: Pearson Correlation

\begin{tabular}{llcccc}
\hline & & $\begin{array}{c}\text { Job } \\
\text { satisfaction }\end{array}$ & $\begin{array}{c}\text { Context } \\
\text { tactics }\end{array}$ & $\begin{array}{c}\text { Content } \\
\text { tactics }\end{array}$ & $\begin{array}{c}\text { Social } \\
\text { tactics }\end{array}$ \\
\hline Job Satisfaction & $\begin{array}{l}\text { Pearson } \\
\text { Correlation }\end{array}$ & 1 & $.238^{* *}$ & $.489^{* *}$ & $.443^{* *}$ \\
& Sig. (2-tailed) & & & & \\
& $\mathrm{N}$ & 254 & .000 & .000 & .000 \\
& & 254 & 254 & 254 \\
\hline
\end{tabular}

**. Correlation is significant at the 0.01 level (2-tailed).

\section{Multiple Regression Analysis}

Multiple regression analysis was conducted to investigate whether context tactics, content tactics, and social tactics could significantly predict job satisfaction. Based on Table 3 below, $R=0.540$, which indicates the moderate relationship between the predictors with job satisfaction. $R^{2}$ indicates the proportion of variation in the outcome variable of the study (job satisfaction) that can be explained by the model. Based on the analysis, $R^{2}$ equal to 0.291 or $29.1 \%$ of the variance in the data can be predicted by the context tactics, content tactics, and social tactics.

Table 3 Model Summary

\begin{tabular}{lcccc}
\hline Model & R & R Square & $\begin{array}{c}\text { Adjusted R } \\
\text { Square }\end{array}$ & $\begin{array}{c}\text { Std. Error of the } \\
\text { Estimate }\end{array}$ \\
\hline 1 & $.540^{\mathrm{a}}$ & .291 & .283 & 3.51394 \\
\hline a. Predictors: (Constant), OST_SOCIAL, OST_CONTEXT, OST_CONTENT
\end{tabular}

Table 4 depicts the coefficient of Multiple Regression Analysis. The result shows that content tactics and social tactics contributed significantly to the model $(\beta=.333, p<.01$ and $\beta$ $=2.67, p<.01$ respectively). While, context tactics did not $(\beta=-.062, p=.304)$. The standardized coefficient shows the magnitude of the coefficients to see which predictor has the greatest effect on job satisfaction. Among the three predictors, content tactics have the strongest effect on job satisfaction with the standardized coefficient .386 . 
Table 4: Correlation Coefficient

\begin{tabular}{lcccc}
\hline & $\begin{array}{c}\text { Unstandardized } \\
\text { Coefficients } \\
\text { (Beta) }\end{array}$ & $\begin{array}{c}\text { Standardized } \\
\text { Coefficients } \\
\text { (Beta) }\end{array}$ & $\mathrm{t}$ & Sig. \\
\hline Context tactics & -.062 & -.065 & -1.029 & .304 \\
Content tactics & .333 & .386 & 5.580 & .000 \\
Social tactics & .267 & .267 & 4.267 & .000 \\
\hline
\end{tabular}

\section{Discussion and Conclusion}

The main purpose of this research is to investigate the role of organizational socialization tactics as the determinants of job satisfaction by using a sample of 254 engineers in Malaysia. Based on the findings of the research and analyses that have been done, two objectives of this research are achieved. By referring to the Pearson's Correlation, all three predictors have a significant impact on job satisfaction, but content and social tactics have a stronger effect as compared to context tactics. This is consistent with the findings by Allen and Shanock (2013) whereby content and social tactics have relationship with the employee outcome. Content tactics explain the extent to which the newcomers are provided with information about the works and organization. An effective onboarding program, for instance, will be meaningful for the newcomers to get correct and required information in performing the work roles (Baeur, 2010).

Equally important, social tactics help newcomers to have a greater fit with the existing members by building a new relationship. Past research reveals that social tactics consistently predict employee outcomes and has the most substantial effect as compared to the other two tactics (Saks et al., 2007). Bauer (2013) further proposed that connection is particularly important during the adjustment process because the interpersonal relationship will create the information network that is meaningful to the newcomer. As a highly skilled employee, engineer needs to have proper training (e.g. onboarding program) to facilitate the adjustment process and ultimately yield to greater satisfaction (Bigliardi et al., 2005). Furthermore, the nature of engineering works requires a professional network to maintain their performance (Baugh and Roberts, 1994). Thus, socialization at the entry-level is of paramount importance to the engineers.

\section{Implication for FUTURE research}

This research is a cross sectional study, thus it may limit the researcher to observe the changes in socialization of engineers resulted from socialization tactics that have been implemented. It is recommended that to conduct a longitudinal study to see how engineers react to the socialization tactics and how these tactics influence their attitudes and behavior in an organization such as the level of satisfaction, commitment and intention to remain. Ashforth, Sluss \& Harrison (2007) have developed the socialization stages model that explain the various stages of socialization of employees, which are anticipation, encounter, adjustment, and stabilization. A longitudinal will help the researcher to monitor the changes in attitude and behavior along these four stages over the years. Secondly, as employees in different organizational context are socialized differently, and the impact on job satisfaction be disparate too. Third, gender role has a significant influence on socialization. Literature on 
gender role socialization proposed that women tend to have a greater tendency to incorporate in social structure and connectedness with others as compared to male counterpart. Thus, it is suggested that to investigate the role of gender in the early work adjustment and produce a piece of new evidence how female engineers adjust themselves in a male-dominated workplace.

\section{Implications for Practice}

In the rise of Industry 4.0, engineers play a pivotal role to plan, solve problem and innovate in defining our future. These tasks require substantial knowledge and skills through education and working experience. On-boarding program can be the best starting point to train the engineer in understanding their job roles and organization's objectives. As employees have different learning and working styles, identifying the best socialization strategy for engineers is of paramount importance. Successful adjustment at the early stage of employment will predict the engineer's attitude towards the job such as organizational commitment and retention. The findings of this research imply that content tactics have the greatest impact on the engineer's intention to leave. Thus, probably signal the practitioners that engineers require sufficient job and organization information immediately after being recruited. This information is important in defining their job roles and later predict their future steps in performing the job.

\section{References}

Abraham, S. (2012). Job satisfaction as an antecedent to employee engagement. SIES Journal of Management, 8(2), 27-36.

Adegoke A. A., Atiyaye F. B., Abubakar A. S., Auta A., Aboda, A. (2015). Job satisfaction and retention of midwives in rural Nigeria. Midwifery, 31(10), 946-956.

Alegre, I., Mas-Machuca, M. and Berbegal-Mirabent, J. (2016). Antecedents of employee job satisfaction: Do they matter? Journal of Business Research, 69, 1390-1395.

Allen, D. G., \& Shanock, L. R. (2013). Perceived organizational support and embeddedness as key mechanisms connecting socialization tactics to commitment and turnover among new employees. Journal of Organizational Behavior, 34(3), 350-369.

Ashforth, B., Sluss, D., \& Harrison, S. (2007). Socialization in organizational contexts. International Review of Industrial and Organizational Psychology, 22, 1-70.

Aziri, B. (2011). Job satisfaction: A literature review. Management Research and Practice. 3(4), 77-86.

Bauer, T. N., \& Green, S. G. (1994). Effect of newcomer involvement in work-related activities: A longitudinal study of socialization. Journal of Applied Psychology, 79(2), 211-223.

Bauer, T. N., Bodner, T., Erdogan, B., Truxillo, D. M., \& Tucker, J. S. (2007). Newcomer adjustment during organizational socialization: A meta-analytic review of antecedents, outcomes, and methods. Journal of Applied Psychology, 92, 707-721.

Baugh, S. G. and Roberts, R. M. (1994). Professional and organizational commitment among engineers: Conflicting or complementing? IEEE Transactions on Engineering Management, 41 (2), 108-114.

Bigliardi, B., Petroni, A. and Dormio, A. I. (2005). Organizational socialization, career aspirations and turnover intentions among design engineers. Leadership \& Organization Development Journal, 26(6), 424-441. 
Bowling, N. A and Hammond, G. D. (2008). Meta-analytic examination of the construct validity of the Michigan Organizational Assessment Questionnaire Job Satisfaction Subscale. Journal of Vocational Behavior, 73, 63-77.

Brayfield, A. H., \& Rothe, H. F. (1951). An index of job satisfaction. Journal of Applied Psychology, 35(5), 307-311.

Cable, D. M., Parsons, C. K. (2001). Socialization tactics and person-organization fit. Personnel Psychology, 54, 1-23.

Cammann, C., Fichman, M., Jenkins, D., \& Klesh, J. (1979). The Michigan Organizational Assessment Questionnaire. Unpublished manuscript, University of Michigan, Ann Arbor.

Chin, C., (2019 February 17). Disheartened engineers leaving the field. Retrieved from: https://www.thestar.com.my/news/nation/2019/02/17/disheartened-engineersleaving-the-field-grads-hampered-by-lack-of-technical-knowhow-and-communicati

Dancey C. P., Reidy, J., Pearson Education (2007). Statistics without Maths for Psychology. New York: Prentice Hall.

Danica Bakotić (2016). Relationship between job satisfaction and organizational performance, Economic Research-Ekonomska Istraživanja, 29(1), 118-130.

Fisher, V. E., \& Hanna, J. V. (1931). The dissatisfied worker. New York, NY, US: MacMillan Co.

Hashim, R. (2015). Levels of job satisfaction among engineers in a Malaysian local organization. Procedia - Social and Behavioral Sciences, 195, 175-181.

Hayes, B., Douglas, C. \& Bonner, A. (2015). Work environment, job satisfaction, stress and burnout among hemodialysis nurses. Journal of Nursing Management, 23, 588-598.

Ho, S. (2018 January 11). Malaysian employees fourth happiest in Asia - JobStreet. Retrieved from:

https://www.theedgemarkets.com/article/malaysian-employees-fourth-happiestasia-\%E2\%80\%94-jobstreet

Hoppock, R. (1935). Job satisfaction. Oxford, England: Harper.

Ismail, A. and Razak, A. M. R. (2016). Effect of job satisfaction on organizational commitment. Management \& Marketing, 12 (1), 25-40.

Jones, G. R. (1986). Socialization tactics, self-efficacy, and newcomers' adjustments to organizations. Academy of Management Journal, 29(2), 262-279.

Judge, T. A., Weiss, H. M., Kammeyer-Mueller, J. D., \& Hulin, C. L. (2017). Job attitudes, job satisfaction, and job affect: A century of continuity and of change. Journal of Applied Psychology, 102(3), 356-374.

Lee, D. M. S. and Allen, T. J. (1982). Integrating new technical staff: Implications for acquiring new technology. Management Science, 28 (12), 1405-1420.

Mathieu, C., Fabi, B., Lacoursière, R., \& Raymond, L. (2016). The role of supervisory behavior, job satisfaction and organizational commitment on employee turnover. Journal of Management \& Organization, 22(1), 113-129.

Mitchell, T. R., \& Larson, J. R., Jr. (Eds.). (1987). People in organizations: An introduction to organizational behavior. New York: McGraw-Hill Book Company.

Morrison, E. W., \& Vancouver, J. B. (2000). Within-person analysis of information seeking: The effects of perceived costs and benefits. Journal of Management, 26(1), 119-137.

Özpehlivana, M. and Acarb, A. Z. (2015). Assessment of a multidimensional job satisfaction instrument. Procedia - Social and Behavioral Sciences, 210, $283-290$. 
Quarstein V.A., McAfee R. B., \& Glassman M. (1992). The situational occurrences theory of job satisfaction. Human Relations. 45, 859-873.

Rollag, K. (2004). The impact of relative tenure on newcomer socialization dynamics. Journal of Organizational Behavior, 25, 853-872.

Saks, A. M., Uggerslev K. L., \& Fassina, N. E. (2007). Socialization tactics and newcomer adjustment: A meta-analytic review and test of a model. Journal of Vocational Behavior, 70, 413-46.

Song, Z., Chon, K., Ding, G., \& Gu, C. (2015). Impact of organizational socialization tactics on newcomer job satisfaction and engagement: Core self-evaluations as moderators. International Journal of Hospitality Management, 46, 180-189.

Spector, P. E. (1997). Job satisfaction: Application, assessment, causes, and consequences. Thousand Oaks, CA: SAGE.

Talentcorp. (2012). Talent Roadmap 2020. Retrieved from http://www.micci.com/resources/Talent-Roadmap-2020.pdf

Terry, A. B. \& Thomas, M. F. (1987). The current debate about the meaning of job stress. Journal of Organizational Behavior Management, 8(2), 5-18.

Thorndike, E. L. (1917). The curve of work and the curve of satisfyingness. Journal of Applied Psychology, 1, 265-267.

Uhrbrock, R. S. (1934). Attitudes of 4430 employees. Journal of Social Psychology, 5(3), 365377.

Maanen, V. J. E., \& Schein, E. H. (1979). Toward a theory of organizational socialization. Research in Organizational Behavior, 1, 209-264.

Vitell, S. J. \& Singhapakdi, A. (2008). The role of ethics institutionalization in influencing organizational commitment, job satisfaction, and esprit de corps. Journal of Business Ethics,83, 343.

Wang, D., Hom, P., \& Allen, D. G. (2017). Coping with newcomer "Hangover": How socialization tactics affect declining job satisfaction during early employment. Journal of Vocational Behaviour, 100, 196-210.

Wanous, J. P. (1992). Organizational entry: Recruitment, selection, orientation, and socialization. Reading, MA: Addison-Wesley.

Weiss, H. M. (2002). Deconstructing job satisfaction: Separating evaluations, beliefs and affective experiences. Human Resource Management Review, 12, 173-194.

Yalabik, Z. Y., Rayton, B. A. and Rapti, A. (2017). Facets of job satisfaction and work engagement. Evidence-based HRM: A Global Forum for Empirical Scholarship, 5 (3), 248-265.

Yang, J. (2010). Antecedents and consequences of job satisfaction in the hotel industry. International Journal of Hospitality Management, 29(4), 609-619.

\section{Acknowledgement}

We thank the UiTM Cawangan Melaka for generously sponsoring this publication. 